\title{
Recorregut de recerca geològica i mineralògica per la comarca valenciana de I'Alt Millars i per I’aragonesa de Gúdar - Javalambre: des de Montanejos a Olba i a Rubielos de Mora
}

\author{
Josep Maria Mata-Perelló \\ Joaquim Sanz Balagué \\ Jaume Vilaltella Farràs
}

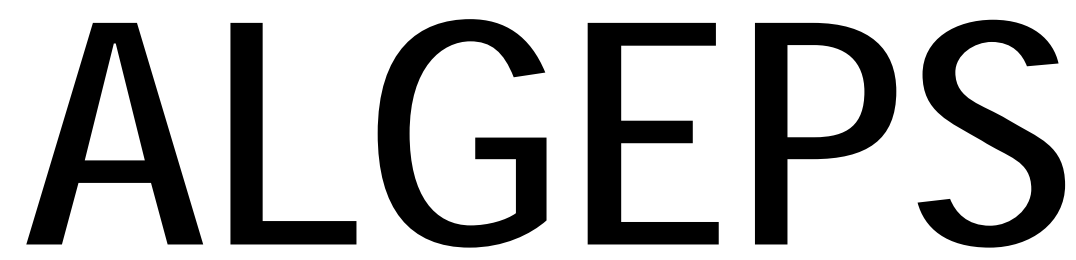

\section{REVISTA DE GEOLOGIA}

\section{n. 1}

GENER 2015 


\title{
RECORREGUT DE RECERCA GEOLÒGICA I MINERALÒGICA PER LA COMARCA VALENCIANA DE L'ALT MILLARS I PER L'ARAGONESA DE GÚDAR - JAVALAMBRE: DES DE MONTANEJOS A OLBA Y A RUBIELOS DE MORA
}

\author{
Josep Maria Mata-Perelló \\ Museu de geologia Valentí Masachs, Escola Politècnica Superior d'Enginyeria de Manresa \\ (EPSEM), Universitat Politècnica de Catalunya · BarcelonaTech (UPC), 08272 Manresa, Spain
}

\author{
Joaquim Sanz Balagué \\ Departament d'Enginyeria Minera i Recursos Naturals (EMRN), Escola Politècnica Superior \\ d'Enginyeria de Manresa (EPSEM), Universitat Politècnica de Catalunya • BarcelonaTech \\ (UPC), 08272 Manresa, Spain
}

\section{Jaume Vilaltella Farràs}

Paraules clau: Patrimoni geològic i miner; Sistema ibèric; País Valencià

\begin{abstract}
Resum
Itinerari realitzat el dia 1 de maig del 2014. Aquest itinerari geològic $i$ mineralògic, discorrerà íntegrament dintre del Sistema Ibèric. Així, anirem trobant estructures d'arrumbament ESE ONO per arreu; tot i així, trobarem fractures de direcció "catalana", NNE - SSO que tallaran a les anteriors, malgrat trobar-nos força lluny de la denominada zona d'Enllaç.

Part del recorregut es situarà dintre dels denominats relleus triàsics de Sagunt (Oriol RIBA et altri, 1976). Tot $i$ així, poc a poc ens anirem endinsant dintre dels sectors anomenats com a muntanyam de Castelló. Així, en la major part dels trajectes anirem trobant afloraments dels diferents materials mesozoics. Aquests es distribueixen segons els indrets entre el Triàsic, el Juràssic i el Cretàcic.
\end{abstract}

Per d'altra banda, en aquest recorregut, anirem circulant prop del riu Millars / Mijares, remuntant-lo des Montanejos fins més enllà d'Olba, passant de la comarca de l'Alt Millars / Alto Mijares a la comarca aragonesa de Gúdar - Javalambre.

Posteriorment, en anar cap a Rubielos de Mora, circularem per la vall del riu Mora, afluent del Millars.

Finalment, cal dir que aquest itinerari transitarà per dues comarques: śiniciarà a la del Alt Millars / Alto Mijares, per a finalitzar a de Gúdar - Javalambre; passant així de la Comunitat Valenciana a la d'Aragó. 


\section{Objectius fonamentals}

Dintre d'aquest itinerari, ens fixarem els següents objectius, d'acord amb el sentit de la marxa del recorregut

1.- Estudi i observació dels materials mesozoics, que constitueixen el Sistema Ibèric, per on discorrerà la totalitat del recorregut de l'itinerari, entre les poblacions de Montanejos (comarca de I'Alt Millars / Alto Mijares) i Rubielos de Mora (comarca del Gúdar - Javalambre). Aquests materials es distribuiran entre el Triàsic (Keuper), Juràssic i Cretàcic, segons els indrets de l'itinerari.

2.- Observació de les estructures del Sistema Ibèric (de direccions generalitzades WNW - ESE i NW - SE) i de les interferències amb les estructures catalanes més minoritàries (de direccions NNE - SSW).

3.- Estudi de diverses mineralitzacions que es vagin trobant al llarg del recorregut, d'acord amb el sentit de la marxa.

4.- Observació d'algunes explotacions mineres (subterrànies o a "cel obert"), antigues 0 actuals, que es vagin trobant al llarg del recorregut.

5.- Observació de l'impacte produït per les explotacions anteriors sobre el medi natural, i si s'escau de les restauracions dutes a terme per reduir aquest impacte.

6.- Observació dels diferents indrets relacionats amb el nostre Patrimoni Geològic i Miner que anem trobant al llarg del recorregut de l'itinerari, i en especial dels que puguin ésser catalogats com a LIG (Llocs d'Interès Geològic) o com a LIPM (Llocs d'Interès del Patrimoni Miner).

\section{Antecedents}

No existeix cap antecedent bibliogràfic relatiu a la totalitat del recorregut d'aquest itinerari. Tot $\mathrm{i}$ així, existeixen alguns antecedents parcials, relatius al primer tram, a MATA - PERELLÓ (2014). I pel que fa als trams finals, a MATA - PERELLÓ et altri (2002). . Tret d'aquests treballs, no en coneixem cap més.

Pel que fa a l'estudi de les mineralitzacions situades al llarg del recorregut, farem un especial esment del treball de MATA-PERELLÓ (1984). També farem esment dels treballs d'inventariat comarcal, de MATA - PERELLÓ (1991), relatiu a la comarca de Gúdar Javalambre; així com a MATA - PERELLÓ (1992), referit a les mineralitzacions de la comarca de I'Alt Millars / Alto Mijares.

Pel que fa a l'estructura geològica dels indrets pels quals discorrerà el recorregut de l'itinerari, farem esment de dos treballs generals, relatius al conjunt dels Països Catalans: GUIMERÀ et altri (1992), i RIBA et altri (1976). Igualment, cal fer esment dels diferents fulls del Mapa Geológico de España corresponents a la zona per la qual discorrerà el recorregut de l'itinerari.

Tots aquests treballs esmentats figuraran per ordre alfabètic a l'apartat dedicat a la bibliografia.

\section{Recorregut de l'itinerari}

El recorregut d'aquest itinerari comença a la comarca de l'Alt Millars / Alto Mijares, per les immediacions de la població de Montanejos, per on es farà la primera aturada del recorregut, prop de la carretera autonòmica $\mathrm{C}-20$. 
Posteriorment, per aquesta mateixa carretera (I'esmentada $C-20)$ el recorregut es dirigirà cap a la Puebla de Arenoso / la Pobla d'Arenós. En aquest tram es realitzaran dues noves aturades, dintre de la comarca de I'Alt Millars / Alto Mijares.

Després el recorregut es dirigirà cap a la població d'Olba. Així, inicialment es transitarà per la mateixa carretera $C-20$, però a l'entrar a la comarca de Gúdar - Javalambre, es transforma en la carretera local aragonesa TE - V - 2001. Per aquesta carretera s'arribarà a I'Estación de Rubielos de Mora. Finalment, des d'aquí caldrà seguir per la carretera autonòmica aragonesa A - 1515, arribant així al poble de Rubielos de Mora. En aquest tram es faran tres noves aturades.

\section{Advertiments previs}

Com en altres recorreguts de recerca geològica i mineralògica ..., si es disposa del temps suficient, poden efectuar-se passant per totes les parades i filloles. En cas contrari, recomanem prescindir de les anomenades parades - condicionals.

També cal tenir en conte que una part del recorregut final de l'itinerari, es realitzarà per camins de terra, per la qual cosa caldrà prendre les degudes precaucions. Així, d'aquesta manera es circularà pels diferents camins d'accés a les mines.

Cal tenir, com sempre, una cura molt especial de respecte a la natura, al llarg de tot el recorregut de l'itinerari, i també fora d'ell.

\section{Descripció de l'ítinerari}

Com en altres itineraris, a continuació veurem una sèrie de "parades o estacions". En cada una d'elles es farà un breu comentari, ja sigui de caràcter geològic, geomorfològic o mineralògic, segons s'escaigui. Per d'altra banda, darrera del nom de l'indret (o de la parada), situarem entre parèntesi el número del Mapa Topogràfic (de I'Instituto Geográfico y Catastral), a escala 1:50.000, on es troba I'indret de l'aturada. En aquesta ocasió, utilitzarem diferents fulls de I'esmentat mapa topogràfic; concretament, dels dos següents: 591 (o de Mora de Rubielos).

Així doncs, la relació general de les aturades que constitueixen aquest itinerari, d'acord amb el sentit de la marxa, és el següent:

\subsection{Parada 1. Fuente de los Baños, carretera de Montanejos a la Pobla d'Arenós, (terme municipal de Montanejos, comarca de l'Alt Millars I Alto Mijares). (Full 614).}

Tot i que el recorregut de l'itinerari el començarem a la població Montanejos, ens caldrà sortir cap el NW per la CV - 20. Així, quasi a la mateixa sortida del poble, ens caldrà deixar-la per tal d'apropar-nos al riu Millars / Mijares, on hi ha la Fuente de los Baños. Aquí farem la primera aturada d'aquest itinerari, a menys de $1 \mathrm{Km}$ del poble.

En aquest recorregut, hem continuat trobant afloraments dels materials mesozoics de la Serralada Ibèrica, per on estem ara situats. Així, fonamentalment, haurem trobat afloraments dels materials carbonatats del Juràssic i del Cretàcic. 


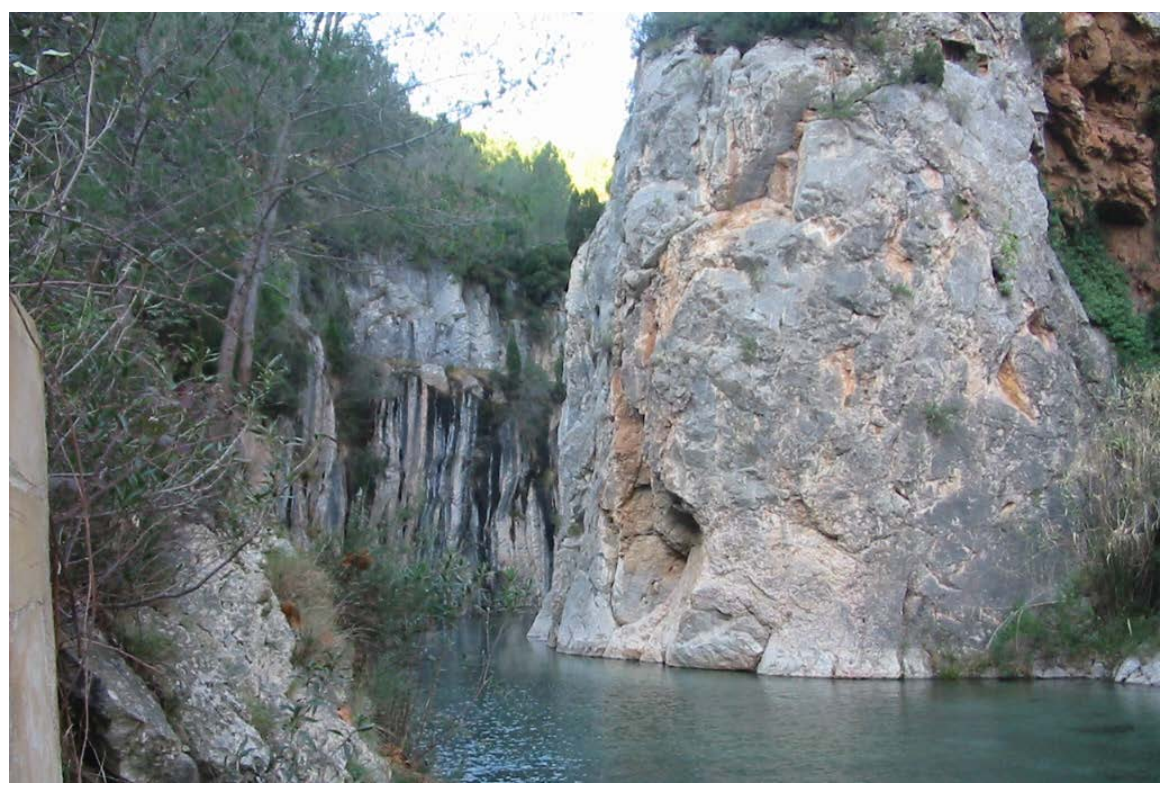

FOTOGRAFIA 1. El riu Millars / Mijares, entre afloraments carbonatats cretàcics. Fuente de los Baños

En aquest indret hi una important surgència d'aigües lleugerament termals (hipotermals) que surten a uns $25^{\mathrm{a}} \mathrm{C}$. Es tracta d'un important naixement d'aigua, d'uns 6000 litres / minut. Just a la sortida hi ha una important formació travertínica. Aquest indret constitueix un important LIG, dintre del nostre Patrimoni Geològic, tot $\mathrm{i}$ trobar-se molt antropitzat. (fotografies 1 i 2 ).

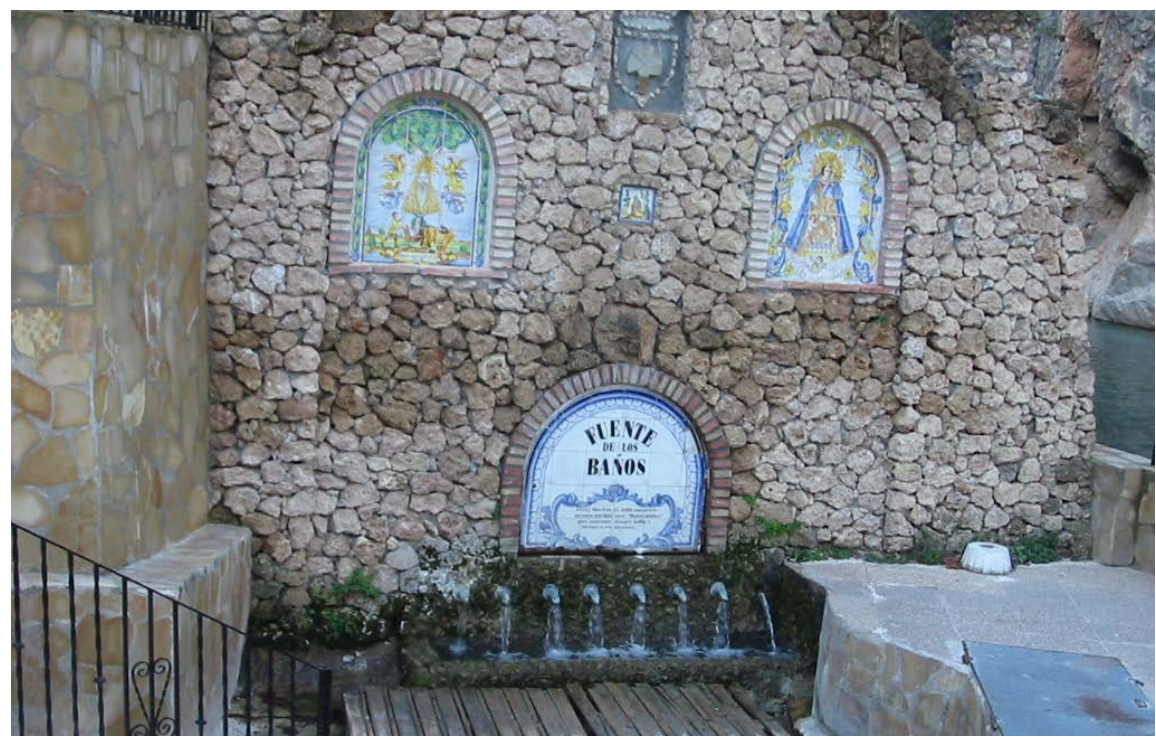

FOTOGRAFIA 2. Un aspecte de la font. 


\subsection{Parada 2. Immediacions de la presa d'Arenós, (terme municipal de Montanejos, comarca de I'Alt Millars I Alto Mijares). (Full 614).}

Després de realitzar l'aturada anterior, cal retornar cap a la carretera C-20, per tal de circular per ella cap el NW, anant en el seu sentit cap a la Puebla de Arenoso / la Pobla d'Arenós. En apropar-nos a la presa, passarem per un interessant congost delimitat pel riu Millars. Prop d'aquest 0 de la immediata pressa, ens caldrà fer una nova aturada a uns $4-5 \mathrm{Km}$ de I'anteriorment realitzada.

En aquest recorregut, haurem trobat afloraments dels materials mesozoics de la Serralada Ibèrica. Aquests són eminentment carbonatats. En travessar-los el riu Millars ha escopit un interessant congost. Aquests materials pertanyen fonamentalment al Cretàcic

En aquest indret es pot veure el congost per on circula el riu Millars i sobre el que s'ha situat la presa d’Arenós.

\subsection{Parada 3 - condicional. Immediacions de la Puebla de Arenoso, (terme municipal de la Puebla de Arenoso I la Pobla d'Arenós, comarca de I'Alt Millars I Alto Mijares). (Full 614).}

Després de realitzar l'aturada anterior, cal retornar cap a la carretera $C-20$, per tal de circular per ella cap a la Puebla de Arenoso I la Pobla d'Arenós. En arribar al poble farem una nova aturada. Així, haurem recorregut uns $5 \mathrm{Km}$ més.

En aquest recorregut hem trobat inicialment els materials carbonatats cretàcics esmentats anteriorment. Tot i així, ara es fan palesos els nivells dels materials argilosos i sorrencs de l’Albià, del Cretàcic Mig.

Des d'aquest indret es pot fer una bona observació de l'embassament d'Arenós, que ha cobert bona part de I'antiga horta del poble de la Puebla de Arenoso.

\subsection{Parada 4. La Hoz, (Collado Royo, terme municipal de San Agustín, comarca de Gúdar-Javalambre). (Full 614).}

Després de fer l'aturada anterior, cal continuar cap el NW per la carretera CV - 20. En arribar al límit comarcal i municipal, aquesta carretera es transforma en la TE - V - 2001, en entrar a la comarca de Gúdar - Javalambre. Seguint per aquesta carretera es passarà pel poble d'Olba. Més endavant s'arribarà a les immediacions del Collado Royo i de la Hoz. Aquí farem una nova aturada, aproximadament a uns $12 \mathrm{Km}$ de I'anterior.

En aquest recorregut, he manat trobant dels materials mesozoics esmentats a les aturades anteriors, els quals formen part de la Serralada Ibèrica, on estem ara situats. Tot i així, en arribar a l'indret de I'aturada, haurem entrat a l'extrem oriental de la Depresión de la Puebla de Valverde - Sarrión, i s'hauran fet palesos alguns afloraments miocènics; tot i que no arriben a veure's, en estar coberts per terrenys travertínics del Pleistocè.

Precisament en aquest indret afloren aquests nivells de travertins, entre els quals el riu Millars I Mijares ha esculpit un interessant congost. (fotografia 3). 


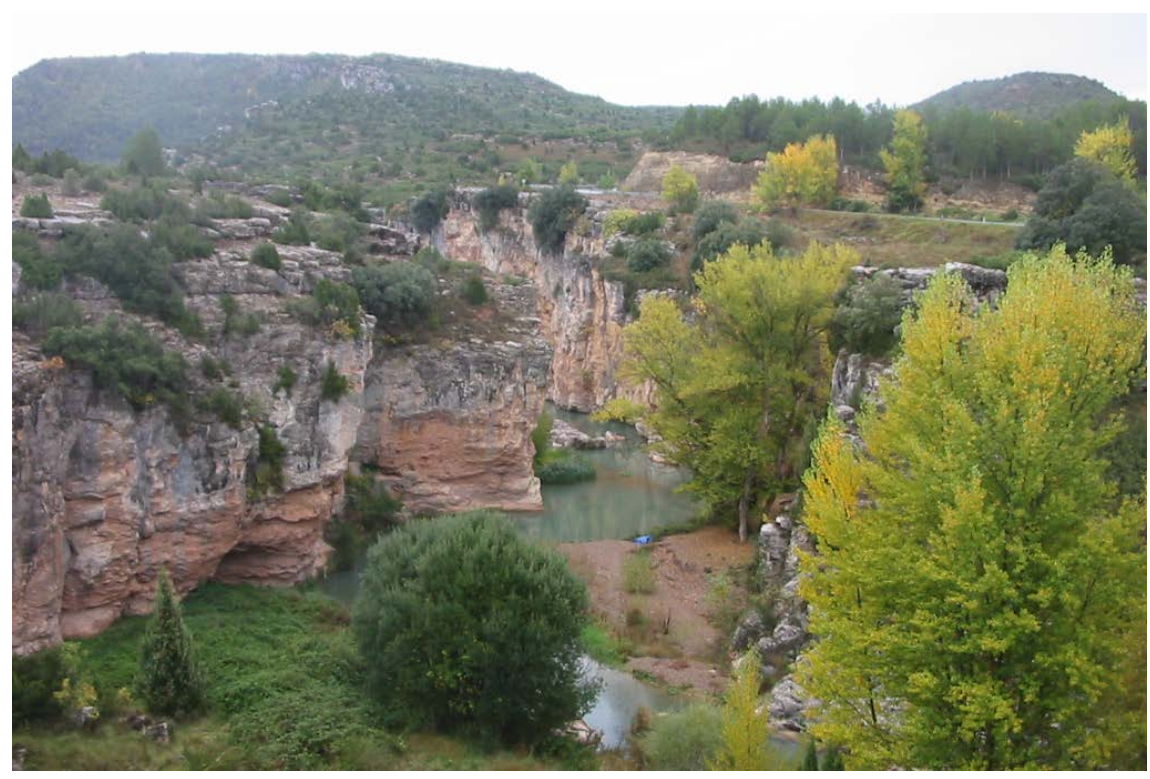

FOTOGRAFIA 3. El Congost del riu Millars, entre els afloraments dels terrenys travertínics.

Cal assenyalar l'interessant valor paisatgístic d'aquest canyó, el qual forma part del nostre patrimoni geològic. Tanmateix, cal valorar la importància d'aquest travertí, sobre el qual s'ha obert pas el riu.

\subsection{Parada 5. Carretera a Rubielos de Mora, río Mijares, la Hoya, (termes municipal de San Agustín i de Mora de Rubielos, comarca de Gúdar- Javalambre). (Full 614).}

Després de realitzar l'aturada anterior, cal continuar per la carretera TE - V - 1002, anant cap a I'Estación de Rubielos de Mora. En arribar-hi, caldrà seguir per la carretera autonòmica aragonesa A - 1515 (la qual condueix cap el poble de Rubielos de Mora). En arribar al paratge de la Hoya, caldrà fer una nova aturada, aproximadament a uns $12 \mathrm{Km}$ de la parada anteriorment realitzada.

En aquest recorregut hem trobat afloraments dels materials detrítics miocènics esmentats a I'aturada anterior. I també n'hem trobat dels materials carbonatats cretàcics. Efectivament, ens hem estat desplaçant per la zona de contacte entre la sierra de Gúdar i la Depresión de la Puebla de Valverde-Sarrión. Sempre dintre del Sistema Ibèric.

En aquest indret, ens tornem a trobar el Cañon del río Mijares / Congost del riu Millars, que ja hem vist a l'aturada anterior. Cal dir que aquí és menys ostensible. Tot i així, l'indret te un gran valor paisatgístic i forma part del nostre Patrimoni Geològic. (fotografia 4).

\subsection{Parada 6. Mines de margues bituminoses de Rubielos de Mora, mina San José, carretera A-1515, (terme municipal de Rubielos de Mora, comarca de Gúdar-Javalambre). (Full 591).}

Després de realitzar l'aturada anterior, cal continuar per la carretera autonòmica A - 1515, la qual es va dirigint cap al poble de Rubielos de Mora. Poc abans d'arribar-hi (a menys de $5 \mathrm{Km}$, caldrà fer una nova aturada. Així, des de la parada anterior, haurem efectuat un recorregut molt proper als 7'5 Km. 


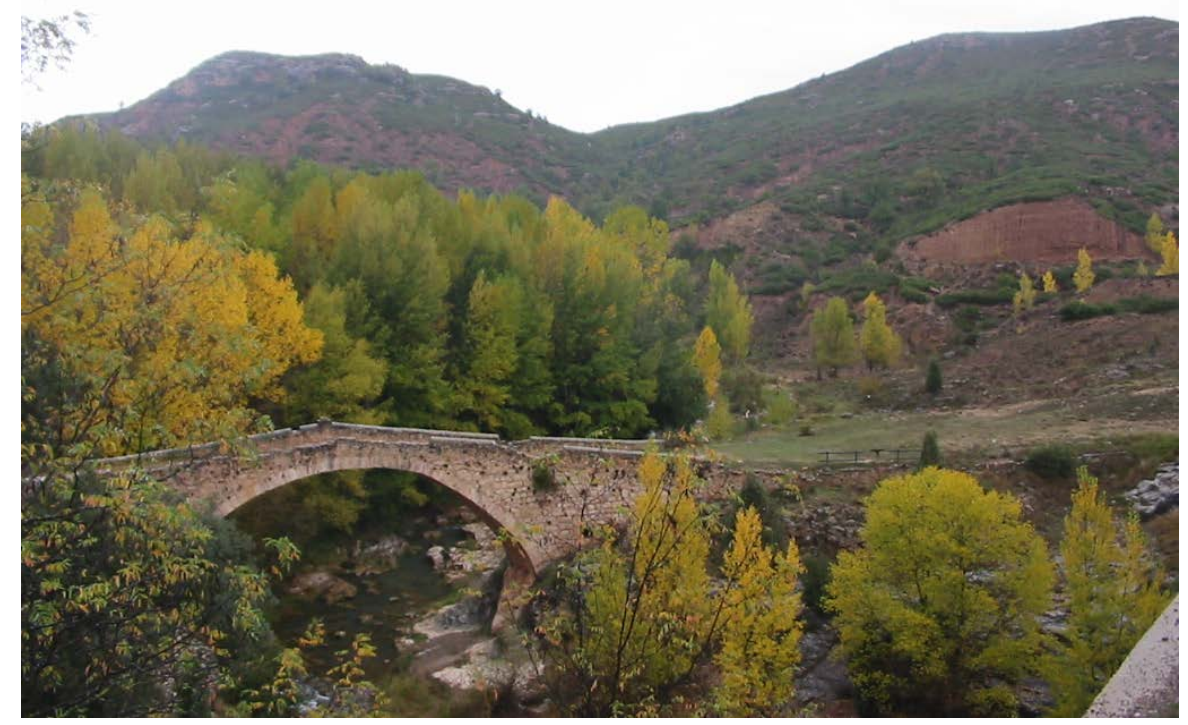

FOTOGRAFIA 4. El Congost del riu Millars / Mijares, entre els afloraments dels terrenys travertínics. La Hoya

La pràctica totalitat d'aquest recorregut, l'hem efectuat entre els afloraments dels materials miocènics de la Depresión de la Puebla de Valverde-Sarrión, de la que hem fet esment a I'aturada anterior; tot i que ara ens trobem situats dintre de la Cubeta de Mora, en aquesta mateixa depressió. Així, per aquest indret afloren per tot arreu uns nivells de lutites i gresos miocènics.

Precisament, sobre aquests darrers materials s' han situat uns depòsits petrolífers; més aviat de nivells bituminosos. Aquests han estat explotats a l'inici i en la primera mitat del segle passat, del segle XX. Aquesta explotació, que no va tenir gaire èxit, ha generat un important patrimoni miner. Aquestes explotacions es van iniciar a l'any 1918, per part de l'empresa catalana Sociedad Sabadell y Henry. (fotografies 5 i 6 ).

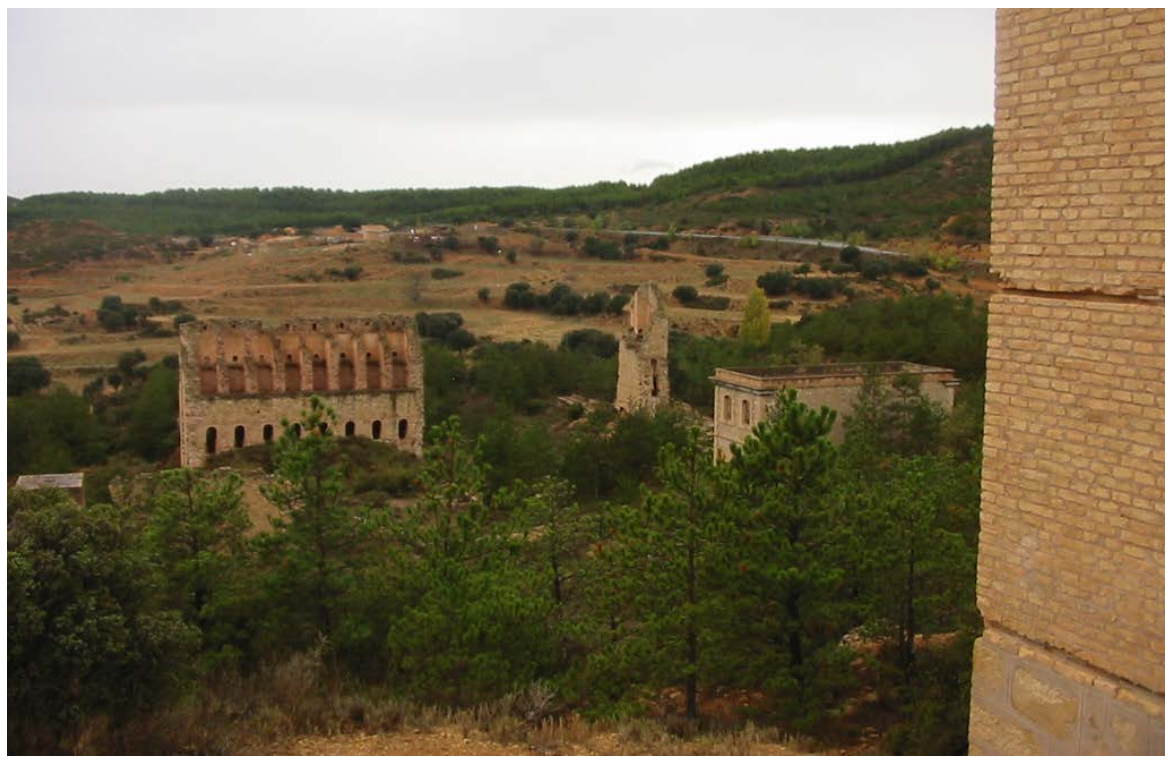

FOTOGRAFIA 5. Un aspecte general de la zona minera bituminosa de Rubielos de Mora 


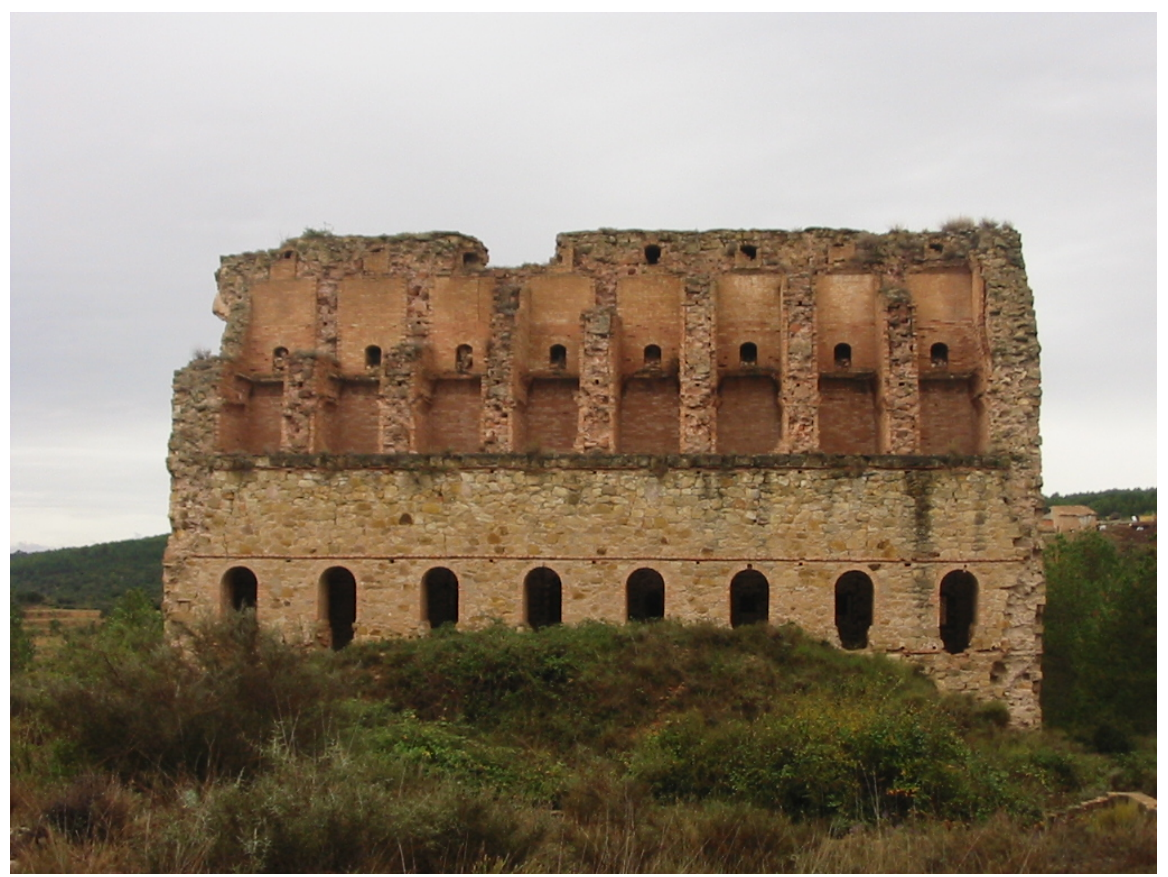

FOTOGRAFIA 6. Zona dels forns de calcinació dels materials bituminosos. Mines de Rubielos de Mora

\subsection{Parada 7 - Condicional. Tejería de Rubielos de Mora, (terme municipal de Rubielos de Mora, comarca de Gúdar-Javalambre). (Full 591).}

Després de realitzar l'aturada anterior, cal retornar cap a la carretera A - 1515, per tal de continuar cap el poble de Rubielos de Mora. Tot i així, uns $2 \mathrm{Km}$ abans d'arribar-hi, es trobarà per l'esquerra un camí que porta a la Fuente del Rull i a la Tejeria de Rubielos de Mora. Ens caldrà agafar aquest camí, per tal de fer una nova aturada, la darrera, en aquest indret. Així, des de la parada anterior, haurem recorregut uns 4’5 K més.

En aquest recorregut, hem anat trobat afloraments dels materials lutitics i calcolutics miocènics (que ja hem esmentat a l’aturada anterior). Efectivament, ens trobem situats a la Depresión de la Puebla de Valverde-Sarrión; i més concretament a la seva Cubeta de Mora.

En aquest indret, es fan paleses les restes d'una antiga teuleria (o rajoleria) l'anomenada Tejería de Rubielos de Mora. Tot i el seu estat de conservació, molt dolent, forma part del Patrimoni Miner de la comarca de Gúdar - Javalambre (fotografia 7).

En aquest indret finalitza l’itinerari. 


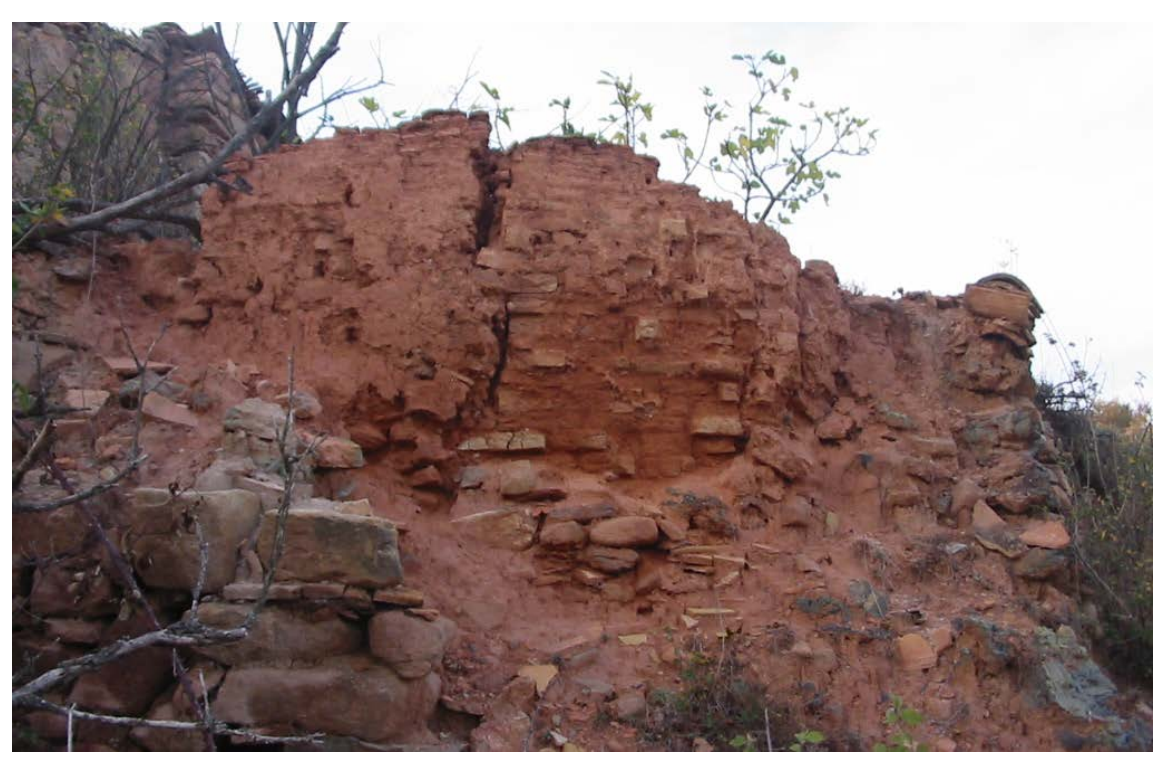

FOTOGRAFIA 7. Un aspecte ruïnós de la Tejería de Rubielos de Mora

\section{BIBLIOGRAFIA}

GUIMERÀ, J. et altri /1992).- Geologia (II), Història Natural dels Països Catalans, Vol.2, 547 pag. Enciclopèdia Catalana, S,A,, Barcelona

LOPEZ, J. i ARCHE, A. (1986).- Estratigrafia del Permico y Triàsico, en facies Buntsandsteim y Muschelkalk, en el sector Sudeste de la rama castellana de la Cordillera Ibérica (Provincias de Cuenca y de Valéncia). Estudios Geológicos, nº. 42, pp. 123-143. Madrid

MATA-PERELLÓ, J.M. (1984).- Els Minerals del País Valencià, Col-lecció Informe, nº 6, 546 pàgines. Manresa

MATA-PERELLÓ, J.M. (1991).- Inventario Mineralógico de la comarca de Gúdar - Javalambre. Rodeno, $n^{\circ} 34.26$ pag. Manresa

MATA-PERELLÓ, J.M. (1992).- Les mineralitzacions de la comarca de I'Alt millars / Alto Mijares (Regió de Sogorb / Segorbe). Algeps, $n^{\circ} 5.23$ pàgines Manresa

MATA-PERELLÓ, J.M. (2002).- Recorrido geológico y mineralógico por la comarca de GúdarJavalambre: desde Sarrión a Allepuz por Linares de Mora y por Valdelinares. Inédito. 10 páginas. Manresa

MATA-PERELLÓ, J.M. i SANZ BALAGUER, J. (1988).- Guia de determinació de Minerals, adaptada als Països Catalans. Parcir, Edicions Selectes, 207 pàgines. Manresa.

MATA-PERELLÓ, J.M, i VILALTELLA FARRÀS, J. (2005a).- Recorregut de recerca geològica i minera per les comarques de l'Alcalatén i de I'Alt Millars: des de Llucena a Argelita. Inèdit, 10 pag. Manresa

MATA-PERELLÓ, J.M, i VILALTELLA FARRÀS, J. (2005b).- Recorregut de recerca geològica i mineralògica per les comarques de la Plana Alta i per l'Alt Millars: des d'Onda a Toga i a Argelita. Inèdit. 8 pàgines. Manresa

RIBA, O. et altri (1976).- Geografia Física dels Països Catalans. Edit. Ketres, 254 pàgines. Barcelona 